\title{
BRYOPHYTE RECORDS FROM THE EASTERN NIGERIAN HIGHLANDS
}

\author{
Izuchuk O. Ezukanma1, Oluwatoyin T. Ogundipe, \\ George I. Nodza \& Tamás Pócs
}

\begin{abstract}
A preliminary inventory of the eastern Nigerian highlands yielded 27 bryophyte species (5 liverworts, 22 mosses), including 13 species new for the country (2 liverworts and 11 mosses). The large percentage of new national records (ca 52\%) indicates that the eastern Nigerian highland has rich bryophyte diversity and is undercollected. A more detailed inventory of the region using more rigorous sampling protocols is recommended.
\end{abstract}

Key words: biodiversity, endemism, highlands, liverworts, mosses, national parks, Nigeria

Izuchuk O. Ezukanma, Oluwatoyin T. Ogundipe \& George I. Nodza, Department of Botany, University of Lagos, Akoka-Yaba, Lagos, Nigeria, 101017; e-mail: izuezukanma@gmail.com

Tamás Pócs, Institute of Biology, Eszterházy Károly University, Eger, Pf. 43, H-3301, Hungary

\section{INTRODUCTION}

Important centers of bryophyte diversity and endemism in Africa are found mostly on isolated mountain massifs and islands (Hodgetts et al. 2000). Most of tropical Africa is arid or semi-arid lowland which is notably less species-rich than tropical America or Southeast Asia, but many parts of Africa, especially the highlands, are known to harbor a rich flora. Most of the mountain massifs in the continent are located in East Africa, especially the Uluguru and Usambara Mountains, which are part of the ancient crystalline mountains of the Eastern Arc located in Tanzania, and the highlands of Ethiopia through the Ruwenzori to Mt. Mulanje in the south. The volcanic peaks of Kilimanjaro, Mt. Kenya, Mt. Elgon and the Virunga Mountains are also very rich in species (Hodgetts et al. 2000).

However, large mountain areas are poorly represented in West Africa, with only three substantial areas above $1000 \mathrm{~m}$ a.s.l.: the Fouta Djallon-LomaNimba massifs, also known as the Guinea highlands, a series of ridges and peaks which rise up to $>1000 \mathrm{~m}$ a.s.l. stretching from Fouta-Djalon in Guinea to the Dans massifs in Ivory Coast

\footnotetext{
1 Corresponding author
}

(Johansson 1974). The two other highlands on the West African mainland are the Jos (Bauchi) Plateau in Nigeria and the highlands of eastern Nigeria and western Cameroon. Others are the islands of Bioko (Fernando Po) and Sao Tomé (Wigginton \& Jones 2004).

While the bryophyte flora of Bioko and Sao Tomé and Principe (Müller \& Pócs 2007; Müller et al. 2007) and western Cameroon (Jones 1990) are fairly well known, there is only a single record of a moss, Wijkia trichocolea (Müll. Hal.) H. A. Crum [syn. Acanthocladium trichocolea (Mull. Hal.) Broth., Sematophyllum trichocolea (Mull. Hal.) Kindb.] (Walters 2017) from the adjoining region in eastern Nigeria. Wijkia trichocolea is widely distributed in East and Central Africa but the only other record for West Africa is from Togo (O'Shea 2006).

There are two sizeable protected areas on the eastern Nigerian highlands that are less degraded by anthropopression. These are the Ngel Nyaki Forest Reserve and Gashaka-Gunti National Park. These two areas are included in this study.

The Ngel Nyaki Forest Reserve $\left(c a 7.2 \mathrm{~km}^{2}\right)$, which is part of the $46 \mathrm{~km}^{2}$ Ngel Nyaki Forest 


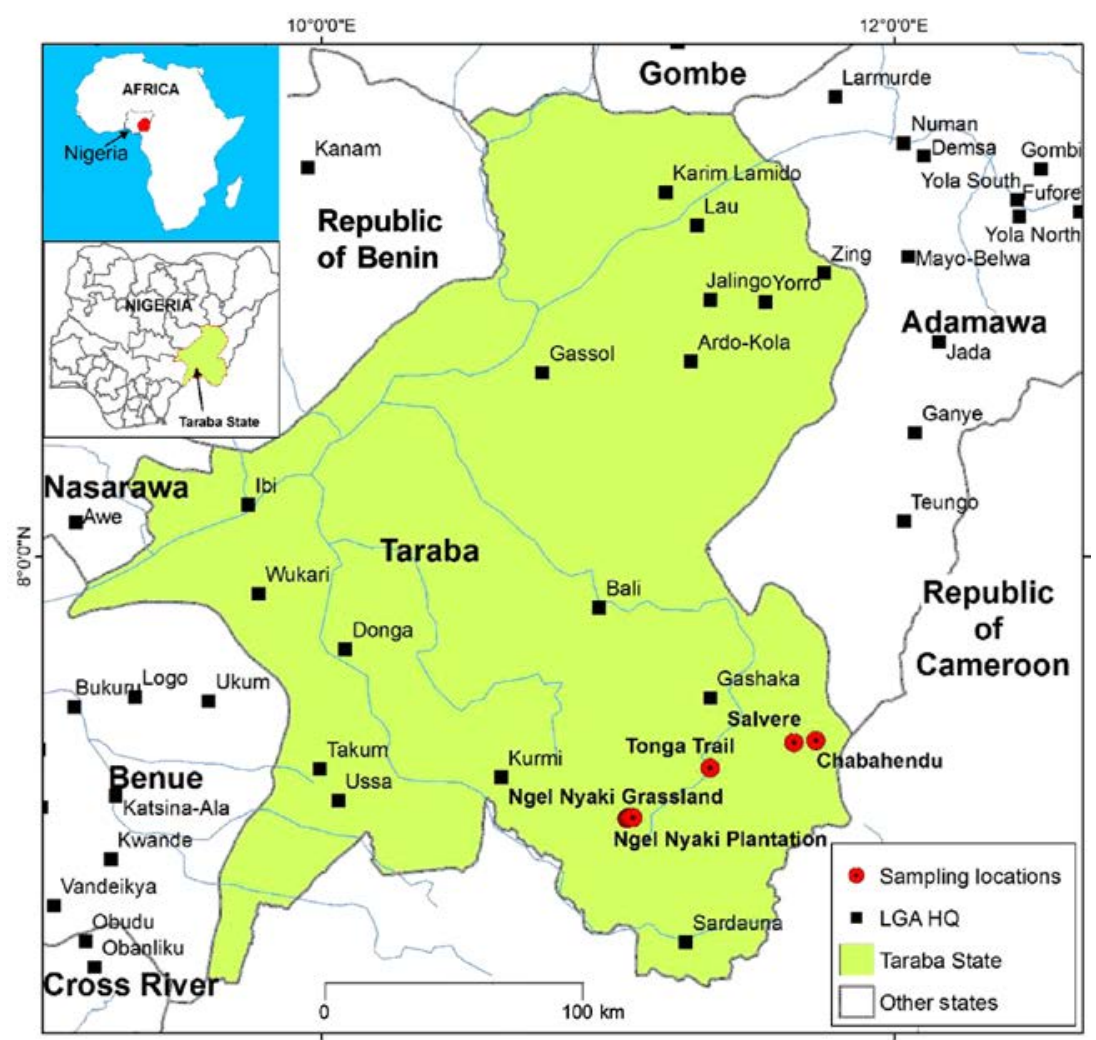

Fig. 1. Map of eastern Nigerian highlands, with sampling points indicated.

Reserve and Game Sanctuary, was gazetted as a local-authority forest under the Gashaka-Mambilla native authority Forest Order in April 1969 (Chapman \& Chapman 2001). It is located towards the western escarpment of the Mambilla Plateau in the southeastern corner of Taraba State, NE Nigeria. The Mambilla Plateau $\left(11^{\circ} 00^{\prime}-11^{\circ} 30^{\prime} \mathrm{E}\right.$, $\left.6^{\circ} 30^{\prime}-7^{\circ} 15^{\prime} \mathrm{N}\right)$ is a highland region which is part of the Cameroon volcanic line, bordering the Republic of Cameroon. The Ngel Nyaki Forest Reserve is in the bowl of an old volcanic crater from 1400-1600 m a.s.l. The forest can be reached on foot from Yelwa village past Mayo Jigawal, from where it is less than an hour's walk to the upper edge of the forest (Ihuma et al. 2011). The forest is drained by numerous watercourses which unite to form the main rivers, then to discharge into the River Benue, Nigeria's second-largest river.

The Ngel Nyaki Forest Reserve is a mosaic of mountain-top grassland, montane and submontane closed canopy forest limited to the stream valleys (Akinsoji 2013). The forest is one of the floristically diverse montane-submontane forest stands in Nigeria (Dowsett-Lemaire 1989) and the most diverse one on the Mambilla plateau (Chapman \& Chapman, 2001).

Gashaka-Gunti National Park $\left(6731 \mathrm{~km}^{2}\right.$; $06^{\circ} 58^{\prime}-08^{\circ} 05^{\prime} \mathrm{N}, 11^{\circ} 11^{\prime}-12^{\circ} 13^{\prime} \mathrm{E}$ ) is the largest protected area within Nigeria, established through a federal decree in 1991 by the merging of two previously existing game reserves (Gumnior \& Soummer 2012): the Gashaka Game Reserve in (present-day) Taraba State, which is the southern section of the reserve; and the Gunti Game Reserve in (present-day) Adamawa State, which is the northern section (Dunn 1995). The park is in a largely secluded mountainous region of northeast Nigeria adjacent to the international border with Cameroon and to the Mambilla Plateau. With the exception of a few lonely footpaths winding 
through the forested mountain towards Cameroon, there is no road across to this region.

The southern sector of the park is mountainous and contains vast expanses of rainforest as well as areas of woodland and montane grassland. The terrain is rugged and is marked by steep, thickly forested slopes, deep plunging valleys, precipitous escarpments and swift-flowing rivers. The terrain in the northern sector is much more amenable, with relatively flat grassland and woodland. Altitude ranges from $450 \mathrm{~m}$ a.s.l. in the wild savannah plains of the northern sector to $2400 \mathrm{~m}$ a.s.1. on the peaks and pinnacles of Gangirwal, which is Nigeria's topmost mountain.

Gashaka-Gunti National Park is considered to be rich in biodiversity (Oates et al. 2004) on account of the intricate mosaic of montane grassland, savannah woodland, swamp, lakes, mighty rivers, dark lowland rainforest, and luxuriant, montane rainforest strewn with ferns and orchids. Each habitat supports its own distinctive community of plants and animals. Equally high mountain ranges in the area act to trap rain-clouds blowing in off the Atlantic Ocean, thus ensuring abundant rainfall, easily enough to support large patches of rainforest throughout the southern park sector. Lowland rainforests are also able to thrive along the park's many river valleys, where they are more correctly known as gallery forests. Mubi and Tukur (2012) reported that plant species diversity and composition varied with altitude; for instance, in the low-altitude range (240-599 $\mathrm{m}$ a.s.1.) the common species included Uapaca togoensis Pax, Crossopteryx februfuga Benth., Brachystegia eurycoma Harms and Andira inermis (W. Wright) DC. The species dominating at 600-1319 m a.s.l. were Daniellia oliveri (Rolfe) Hutch. \& Dalziel, Hymenocardia acida Tul. and Terminalia glaucescens Planch. ex Laness., while in the $1320-1885 \mathrm{~m}$ a.s.l. range the notable species were Combretum spp., Entada africana Guill. \& Perr. and Lannea schimperi Engl. However, there is no record of bryophytes from this region.

The two protected areas on the eastern Nigerian highlands share similar climatic conditions. There is usually a marked wet season from April to November when virtually all rains fall, with many rainy days, although the timing and amount of rain falling each year is highly variable. The dry season is usually from December to March when little or no rains fall, with severe atmospheric aridity and great extremes of temperature. The onset of the season is marked by dry, sand-laden Harmattan winds blowing down from the northeast off the Sahara Desert. The climatic conditions in the park are highly variable and depend on elevation, topography and location. The forested basin below Chappal Waddi, where the southern sector of the park faces and intercepts the inbound prevailing southwesterly moisture-laden winds from the Atlantic Ocean, corresponds to the wettest areas, with mean annual precipitation in excess of $3000 \mathrm{~mm}$. The driest regions of the park are in the northern sector, with a shorter rainy season often lasting only from May to October, with mean annual rainfall less than $1300 \mathrm{~mm}$. Daytime temperatures may reach $40^{\circ} \mathrm{C}$ in the shade around March but tend to drop below $5^{\circ} \mathrm{C}$ at higher altitudes in December. Sudden storms and hail are common occurrences on Gangirwal Mountain.

During a research and collection expedition by the University of Lagos Ecology Research Group in November 2015, a random collection of bryophytes was gathered by Izuchuk O. Ezukanma (IE), mostly from substrates along the trail on the ascent to the mountains and numerous streams and river courses, without recourse to any sampling protocol or attempts to distinguish species in the field (see Fig. 1 and Table 1). Voucher specimens are deposited at the University of Lagos Herbarium (ULH). Nomenclature follows Söderström et al. (2015) and Wigginton $(2004,2009)$ for liverworts, and O'Shea $(1995,2006)$ for mosses. Species new to Nigeria are asterisked $\left(^{*}\right)$.

\section{ENUMERATION OF SPECIES}

\section{MARCHANTIOPHYTA}

${ }^{*}$ Cheilolejeunea montagnei (Gottsche ex Mont.)

\section{R. M. Schust.}

SPeCimen EXAmined. On exfoliating Eucalyptus tree bark at less than 2 m height on trunk in Eucalyptus plantation, Nyel-Nyaki, Yelwa, Mambilla Plateau, $1600 \mathrm{~m}$ a.s.1., 18 Nov. 2015, IE 019. 
Table 1. Selected sampled sites and substrates on the eastern Nigerian highlands.

\begin{tabular}{lcll}
\hline Location & Elevation & Geographical coordinates & Substrate \\
\hline \multirow{2}{*}{ Ngel Nyaki Grassland } & 1691 & $7.08514^{\circ} \mathrm{N}, 11.06972^{\circ} \mathrm{E}$ & Termite mounds \\
& 1692 & $7.08543^{\circ} \mathrm{N}, 11.07065^{\circ} \mathrm{E}$ & \\
\hline Ngel Nyaki Plantation & 1602 & $7.08892^{\circ} \mathrm{N}, 11.07792^{\circ} \mathrm{E}$ & Eucalyptus sp. \\
\hline Tonga trail & 1144 & $7.26283^{\circ} \mathrm{N}, 11.35927^{\circ} \mathrm{E}$ & $\begin{array}{l}\text { Exposed and sheltered } \\
\text { rocky outcrops }\end{array}$ \\
\hline Salvere & 1187 & $7.21243^{\circ} \mathrm{N}, 10.36051^{\circ} \mathrm{E}$ & Dracaena mannii \\
\hline Chabahendu & 1628 & $7.35147^{\circ} \mathrm{N}, 11.65147^{\circ} \mathrm{E}$ & Termite mound \\
\hline
\end{tabular}

Cheilolejeunea montagnei is mostly a highaltitude species collected mainly from Rwenzori, Kenya, Tanzania and Reunion Island. In West Africa the only known record is from São Tomé, where it has been collected repeatedly (Wigginton 2009). This is the first collection of the species in Nigeria.

\section{${ }^{*}$ Lejeunea brenanii E. W. Jones}

SPeCimens EXAmined. Corticolous on Terminalia sp. near stream, growing in mixed population with Hyophila involuta and Heterophyllium bulbiliferum, Chabahendu, Gashaka-Gunti National Park, 1600 m a.s.l., 14 Nov. 2015, IE 002A \& IE 002B; growing on Eucalyptus trees in plantation in Ngel-Nyaki, Mambilla Plateau, in mixed population with Heterophyllim bulbiliferum, $1600 \mathrm{~m}$ a.s.1., 18 Nov. 2015, IE 16 \& IE 21.

Lejeunea brenanii is known only from the Krokosua Hills, Ghana (Jones 1979). This is the first record of the species outside Ghana.

\section{Mastigolejeunea nigra Steph.}

SPECIMEN EXAMINED. Exfoliating bark of Eucalyptus trees in plantation on road to Ngel-Nyaki Forest Reserve, Yelwa, Mambilla Plateau >1600 m a.s.l., 18 Nov. 2015, IE 015 \& IE 018.

Mastigolejeunea nigra is a widely distributed Pantropic species associated with tree crop plantations, especially cocoa agroforest in the Neotropics (Gradstein 1999; Andersson \& Gradstein 2005). In Nigeria almost all the reported collections were in cocoa plantations in and around Ibadan, southwest Nigeria (Akande et al. 1982; Akande 1985; Ezukanma 2012), likewise in Sulawesi, Indonesia (Ariyanti 2008), and in other forms of managed vegetation landscape (Ezukanma et al., unpublished).

\section{Lejeunea conformis Nees \& Mont.}

Taxilejeunea conformis (Nees \& Mont) Steph.

SPECIMEN EXAMINED. Exfoliating bark of Eucalyptus tree in plantation on road to Ngel-Nyaki Forest Reserve, Yelwa, Mambilla Plateau, growing together with Heterophyllium bulbiliferum, $1600 \mathrm{~m}$ a.s.1., 18 Nov. 2015, IE $022 B$.

Lejeunea conformis is known mostly from montane regions. It is fairly widely distributed in Africa. In West Africa it is reported from Cameroon, Nigeria, Togo, Ghana, Ivory Coast and Sierra Leone (Wigginton 2009).

\section{Plagiochila fusifera Taylor}

Specimen examined. Corticolous on Dracaena mannii, Salvere, Gashaka-Gunti National Park, 1500 m a.s.1., 14 Nov. 2015, IE 024.

Plagiochila fusifera is known from lowland areas and is abundant in West Africa from Cameroon to Senegal but is unknown from the Gulf of Guinea islands (Wigginton 2009). This is the first record from the montane region of West Africa.

\section{BRYOPHYTA}

\section{*Acroporium megasporum (Duby) Fleisch.}

Specimen EXAmined. On tree trunk at around breast height, Gashaka-Gunti National Park, 1500 m a.s.l., 12 Nov. 2015, IE 013.

Acroporium megasporum is known from the Indian Ocean Islands and from Tanzania in East Africa (O'Shea 2006), and from Rio Muni, Cameroon and Gabon in West Africa (O'Shea 2006). Our specimen is sterile but the features correspond to the illustrations and description of Petit (1978). 
Campylopus chevalieri Broth. \& Thér.

Specimen examined. On base of Syzygium sp. near stream at Chabahendu, Gashaka-Gunti National Park, Taraba State, Nigeria, 1600 m a.s.1., 12 Nov. 2015, IE $001 A$.

Campylopus chevalieri is known from West and Central Africa (Frahm 1985; O' Shea 2006).

\section{Campylopus savannarum (Müll. Hal.) Mitt.}

SPECimens EXAmined. On base of Syzygium sp., mixed with Campylopus chevalieri, IE 001B; on termite mounds, Ngel-Nyaki, Yelwa, Mambilla Plateau $1600 \mathrm{~m}$ a.s.l., IE 035; on exposed rock along bush path on ascent to Tonga, Gashaka-Gunti National Park, $600 \mathrm{~m}$ a.s.l., 12 Nov. 2015, IE 051.

Campylopus savannarum is widely distributed in sub-Saharan Africa (Frahm 1985; O'Shea 2006) and the Neotropics (Bowers 1974; Allen 1994; Frahm 1982). The only record outside Africa and the Neotropics is from the Philippines (Tan \& Iwatsuki 1991). Records of this species from Nigeria are few. Egunyomi (1984) reported a collection from the Idanre Rocks, Southwest Nigeria.

\section{*Daltonia angustifolia Dozy \& Molk.}

Specimens eXAmined. On termite mounds in frequently grazed grassland, Ngel-Nyaki, Mambilla Plateau, 1600 m a.s.l., Nov. 2015, IE 034, IE 040, IE 043, IE 044.

Daltonia angustifolia var. angustifolia is recorded from a few countries in eastern and southern Africa and from the Indian Ocean islands of Madagascar and Reunion. The only record outside these regions is from Cameroon, West Africa. (O’Shea 2006).

\section{Erythrodontium barteri (Mitt.) Broth. (cf.)}

SPECIMEN EXAmined. On sheltered rock near stream, Kwano, Gashaka-Gunti National Park, 500 m a.s.l., 12 Nov. 2015, IE 047; on exposed rock along bush path on ascent to Tonga, Gashaka-Gunti National Park, $600 \mathrm{~m}$ a.s.1., 12 Nov. 2015, IE 051, IE 053, IE 056.

Erythrodontium barteri is known mostly from West and Central African countries (O'Shea 2006).

\section{Eurhynchium spiculosum (Mitt.) A. Jaeger}

SPeCimen eXAmined. Corticolous on Dracaena mannii, Salvere, Gashaka-Gunti National Park, 1500 m a.s.1., 14 Nov. 2015, IE 024.
Eurhynchium spiculosum was originally known only from Cameroon (Schulze-Motel 1975; O’Shea 1995) and later was collected from Bioko in Nigeria as well (O’Shea 2006).

\section{"Heterophyllium bulbiliferum Dixon.}

Specimens eXamined. Corticolous and common on Terminalia sp. and tree stumps near stream, Chabahendu, Gashaka-Gunti National Park, 1600 m a.s.l., 13 Nov. 2015; growing together with Hyophila involuta, 14 Nov. 2015, IE 002B \& IE 006; partly submerged rock along stream course, Kwano, Gashaka-Gunti National Park, $520 \mathrm{~m}$ a.s.l., IE 049, on Eucalyptus tree in plantation on road to Ngel-Nyaki Forest Reserve, Yelwa, Mambilla Plateau, $1600 \mathrm{~m}$ a.s.l., 18 Nov. 2015, IE 016, IE 017, IE $022 \mathrm{~A}$.

Heterophyllium bulbiliferum is known only from Mt. Cameroon (Dixon 1933; Schulze-Motel 1975; O'Shea 2006).

\section{Hyophila involuta (Hook.) A. Jaeger}

Gymnostomum involutus Hook.

Specimen EXAmined. Corticolous on Terminalia sp. near stream, Chabahendu, Gashaka-Gunti National Park, in mixed population with Heterophyllium bulbiliferum, $1500 \mathrm{~m}$ a.s.1., Nov. 2015, IE $002 \mathrm{~A}$.

Hyophila involuta is widely distributed throughout the tropics and warmer temperate regions of the world. (O'Shea 2006; Eckel 2007). It was recorded from Nigeria first by Sollman (2013).

\section{*Isopterygium antunesii Broth.}

Specimen examined: On bare soil, shaded forest floor, Ngel-Nyaki Forest Reserve, Mambilla Plateau, 1600 m a.s.1., 18 Nov. 2015, IE 039.

Isopterygium antunesii is known only from Angola (Kis 1985; O'Shea 2006). This is the second global record.

\section{${ }^{*}$ Mniobryum ruwenzorense P. de la Varde}

Specimen examined. On rock near Mayodim Stream, very close to turbine, Kwano, Gashaka-Gunti National Park, 520 m a.s.1., 11 Nov. 2015, IE 055.

Mniobryum ruwenzorense is known only from Uganda (Kis 1985; O'Shea 2006). This is the second global record. 
Pelekium gratum (P. Beauv.) Touw

Hypnum gratum P. Beauv.

Specimen exAmined. Rock on forest floor near stream, Kwano, Gashaka-Gunti National Park, $500 \mathrm{~m}$ a.s.1., 11 Nov. 2015, IE 046.

Pelekium gratum is a widely distributed moss known from tropical Africa, Asia, northern Australia and the Pacific (mapped by Touw 1976).

Pelekium investe (Mitt.) Touw

Hypnum investe Mitt.

Specimen eXamined. On rock near stream, Kwano, Gashaka-Gunti National Park, 520 m a.s.1., 11 Nov. 2015, IE 010 \& IE 050.

Pelekium investe is a palaeotropical species known from tropical Central and West Africa through Asia to the Society Islands in the South Pacific (Touw 2001).

Philonotis hastata (Duby) Wijk \& Margad.

Hypnum hastatum Duby

Specimen examined. On termite mounds in frequently grazed grassland, Ngel-Nyaki, Mambilla Plateau, 1600 m a.s.l., 18 Nov. 2015, IE 033, IE 036, IE 038, IE 041, IE 042 .

Philonotis hastata is a Pantropical species (Allen 1999, 2002), widely distributed in Africa (O’Shea 2006).

\section{*Pogonatum capense (Hampe) A. Jaeger}

Polytrichum transvaaliense Müll. Hal.

SPECIMEN EXAMINED. Exposed rocky outcrop along bush path, Gashaka-Gunti National Park, 12 Nov. 2015, IE 011.

Pogonatum capense is known from Angola, Zimbabwe, South Africa, Mauritius and Madagascar (De Sloover 1986; Hyvönen 1989; Manyanga \& Perold 2004; O'Shea 2006).

*Porotrichum stipitatum (Mitt.) W. R. Buck

Porothamnium leptopteris (Müll. Hal. ex Dusén) M. Fleisch.

Specimen eXAmined. On rock near stream, Kwano,
Gashaka-Gunti National Park, 520 m a.s.1., 11 Nov. 2015, IE 048.

Porotrichum stipitatum is an Afro-American disjunct, widely distributed in Africa (De Sloover 1983; O’Shea 2006).

${ }^{*}$ Rhachitheciopsis tisserantii P. de la Varde (cf.)

Rhachithecium tisserantii (P. de la Varde) H. Rob.

Specimen exAmined. On termite mounds in frequently grazed grassland, Ngel-Nyaki, Mambilla Plateau, 1600 m a.s.1., 18 Nov. 2015, IE 007.

Rhachitheciopsis tisserantii is known only from the Central African Republic and the Democratic Republic of the Congo (Schultze-Motel 1975; O'Shea 2006). This is the first report outside the Central African region.

\section{* Sematophyllum brachytheciiforme (Broth.)}

Broth.

Rhaphidostegium brachytheciforme Broth.

Specimen eXAmined. On base of Syzygium sp. near stream at Chabalendu in mixed population with Campylopus savannarum and Campylopus chevalieri, 1600 m a.s.l., IE 001; on Dracaena mannii, Salvere, Gashaka-Gunti National Park, 1500 m a.s.l., IE 003; on Terminalia ca $20 \mathrm{~m}$ from stream, Chabahendu, GashakaGunti National Park, IE 004; on Eucalyptus tree, NgelNyaki, Yelwa, Mambilla Plateau, 1500 m a.s.l., 12 Nov. 2015, IE 008; on termite mounds in frequently grazed grassland, Ngel-Nyaki, Mambilla Plateau, 1600 m, Nov. 2015, IE 037.

Sematophyllum brachytheciiforme is known only from Cameroon, Democratic Republic of the Congo and Rwanda (O’Shea 2006).

*Stereophyllum macrocarpum J. Taylor \& P. de la Varde

SPECIMEN eXAmined. On Dracaena mannii Salvere, Gashaka-Gunti National Park, 1500 m a.s.l., 12 Nov. 2015, IE 023.

Stereophyllum macrocarpum is known only from Ethiopia (O'Shea 1995, 2006). This is the second global record.

Stereophyllum radiculosum (Hook.) Mitt.

Hookeria radiculosa Hook. 
SPECIMENS EXAMINED. On rock near stream, Kwano, Gashaka-Gunti National Park, 520 m a.s.l., 11 Nov. 2015, IE 054; exposed rocky trail, on ascent to Tonga from Kwano, Gashaka-Gunti National Park, $1500 \mathrm{~m}$ a.s.1., 12 Nov. 2015, IE 012.

Stereophyllum radiculosum is widely distributed in mainland Africa and the Indian Ocean islands of Madagascar and Reunion. Although there is no record from the islands of the Gulf of Guinea, it is recorded across the Atlantic from Brazil and Mexico (Forzza 2010; Delgadillo Moya \& Cárdenas Soriano 2011; Tropicos.org).

Thidium involvens subsp. thomeanum (Broth.) Touw

SPeCimen eXAmined. On exposed rock along bush path on ascent to Tonga, Gashaka-Gunti National Park, 600 m a.s.1., 12 Nov. 2015, IE 009.

Thidium involvens subsp. thomeanum is widely distributed in West and Central Africa, including the Gulf of Guinea island of São Tomé. (Touw 1976; O’Shea 2006; Tropicos.org)

\section{${ }^{*}$ Trichosteleum humbertii P. de la Varde}

Specimen examined. On Eucalyptus tree in plantation on road to Ngel-Nyaki Forest Reserve, Yelwa, Mambilla Plateau 1600 m a.s.1., 18 Nov. 2015, IE 020.

Trichosteleum humbertii is known from the Great Lakes region of Africa: Burundi, Democratic Republic of Congo, Kenya, Rwanda and Tanzania (Kis 1985; Bos et al. 1993; O'Shea 2006). This is the first record of the species in West Africa outside the Great Lakes region.

\section{Trichosteleum papillosum (Hornsch.) Jaeger}

Specimen EXAmined. On fallen tree near stream, Chabahendu, Gashaka-Gunti National Park. $1600 \mathrm{~m}$ a.s.l., 12 Nov. 2015, IE 004, IE 005, IE 008; Terminalia ca $20 \mathrm{~m}$ from stream, Chabahendu, Gashaka-Gunti National Park. In mixed population with Trichosteleum humbertii P. de la Varde, 12 Nov. 2015, IE 004.

Trichosteleum papillosum was first reported from Panama (Crosby 1969) but is known also from Brazil (Forzza 2010) and Columbia (Florschütz-de Waard \& Florschutz 1979). In Africa it is known only from Nigeria (SchultzeMotel 1975).

\section{DisCUSSION}

These 27 bryophyte species, comprising 5 liverworts and 22 mosses, were recorded for the first time from a random, nontargeted collection of bryophytes from various substrates on the eastern Nigerian highlands and environs in Taraba State, Nigeria. Mosses dominate a similar nontargeted collection from a Mozambique highland forest (Hedderson et al. 2015).

In the present study, nearly $50 \%$ of the recorded species are new national records for Nigeria. This is a clear sign that the bryophyte diversity (and possibly endemism) of the region is high. A more detailed survey with rigorous sampling protocols such as those of Newmaster et al. (2005) will no doubt prove worthwhile. The eastern Nigerian highlands are known to be a poorly collected region; it is one of the important gaps in our knowledge of the West African bryoflora (Wigginton $\&$ Jones 2004). As expected, there is a close affinity between the species on the eastern Nigerian highlands and the records from the adjoining western Cameroon highland (Dixon 1932, 1933) and contiguous countries such as Gabon, Central African Republic, Democratic Republic of Congo and the isolated Gulf of Guinea islands of Bioko and São Tomé. However, the distribution of many bryophyte species from this collection are more related to eastern and southern Africa and the (western) Indian Ocean islands of Madagascar, Comoros and Reunion than to the records from West Africa. For instance, only one species (Lejeunea brenanii) out of the 14 new records for Nigeria is known from Ghana, West Africa, while the rest are known from eastern and southern Africa. Keay (1953) observed a related pattern in the phanerogam flora on the Jos-Bauchi Plateau, where many species were found not to occur elsewhere in West Africa but are identical with those from eastern and southern Africa. Likewise, the liverwort collection on the Jos Plateau gathered by E. A. Drew in 1962 were consistent with Keay's (1953) phanerogam distributional pattern on the Jos-Bauchi Plateau. (Wigginton \& Jones 2004).

Previously, 136 liverwort species and 141 moss species were known from Nigeria (Wigginton 
2009; Frahm 2003). The addition of 2 liverwort species and 11 moss species new for Nigeria marginally increases Nigeria's bryophyte species tally. A more rigorous sampling and collection expedition on the highlands of Nigeria is likely to substantially increase the national records and provide more information on the distribution and phytogeography of the Nigerian bryoflora.

ACKNOWLEDGEMENTs. We are grateful to the following persons and institutions for their invaluable help. Dr. Hazel Chapman of the Nigerian Montane Forest Project and Dr. Volker Sommer of the Gashaka Biodiversity Project accommodated us in their research stations during the fieldtrip. Dr. Jerome Degreef, Curator of Cryptogams, National Botanic Garden of Belgium, Meisse, provided taxonomic treatments for African species. Professor A. Egunyomi assisted with the identification and authentication of difficult species. Professors S. Robbert Gradstein and Janice Glime shared reprints of their papers, read through the manuscript and made useful comments. Professor Gradstein assisted us with a complimentary copy of the Guide to Bryophytes of Tropical America. Dr. N. H. Amaeze and Mr. S. O. Faton, Department of Zoology, University of Lagos, made their laboratory space available to us during manuscript preparation. Mr. Youpele Appiah, Nigerian Institute of Oceanography and Marine Research, assisted with the map. The anonymous reviewer contributed useful corrections and suggestions to improve the manuscript.

\section{REFERENCES}

Akande A. O., Olarinmoye S. O. \& Egunyomi A. 1982. Phytosociological studies of some corticolous bryophytes in Ibadan, Nigeria. Cryptog. Bryol. Lichenol. 3(3): 235-248.

AKANDE A. O. 1985. Ecological physiology of corticolous bryophytes around Ibadan, PhD Thesis. Department of Botany, University of Ibadan, Ibadan.

Akinsoji A. 2005. A survey of montane epiphytes in GashakaGunti National Park, Nigeria. Nigerian J. Bot. 18: 35-45.

Allen B. H. 1994. Moss Flora of Central America. Part 1. Sphagnaceae-Calymperaceae. Monogr. Syst. Bot. Missouri Bot. Gard. 49: 1-242.

Allen B. H. 1999. The genus Philonotis (Bartramiaceae Musci) in Central America. Haussknechtia Beih. 9: 19-36.

Allen B. H. 2002. Moss flora of Central America, Part 2. Encalyptaceae-Orthotrichaceae. Monogr. Syst. Bot. Missouri Bot. Gard. 90: viii + 1-699.
ANDERSSON M. S. \& GRADSTEIN S. R. 2005. Impact of management intensity on non-vascular epiphyte diversity in cacao plantation in western Ecuador. Biodivers. \& Conservation 14: $1101-1120$.

Ariyanti N. S., Bos M. M., Kartawinata K., Tuitrosoedirjo S. S., Guhardja E. \& Gradstein S. R. 2008. Bryophytes on tree trunks in natural forests, selectively logged forests and cacao agroforests in Central Sulawesi, Indonesia. Biol. Conservation 141: 2516-2527.

Bowers F. D. 1974. The mosses reported from Costa Rica. Bryologist 77: 150-171.

Chapman J. D. \& Chapman H. M. 2001. Forest of Taraba and Adamawa State, Nigeria. An Ecological Account and Plant Species Checklist. University of Canterbury, Christchurch, New Zealand.

Crosby M. R. 1969. Mosses reported from Panama. Bryologist 72: 513-521.

De Sloover J. L. 1983. Note de bryologie africaine XII. Porotrichum et Porothamnium. Bull. Jard. Bot. Natl. Belg. 53: 97-152.

De Sloover J. L. 1986. Note de bryologie africaine XIII. Polytrichaceae. Bull. Jard. Bot. Natl. Belg. 56: 241-300.

Delgadillo C. M. \& Soriano C. A. 2011. In: A. J. GarCíA-Mendoza \& J. A. Meave (eds), Diversidad floristica de Oaxaca, pp. 137-148. Universidad Nacional Autónoma de México, Ciudad Universitaria, Oaxaca.

Dixon H. N. 1932. On the moss Flora of Siam. J. Siam Soc. Nat. Hist. Suppl. 9: 1-51.

Dixon H. N. 1933. Mosses collected on Mt. Cameroon. Ann. Bryol. 6: 20-30.

Dowsett-Lemaire F. 1989. Physiography and vegetation of highland forests of eastern Nigeria. Tauraco Research Report 1: 6-12.

DunN A. 1995. Gashak-Gunti, Nigeria from game reserve to national park. Russell Press Ltd. Nottingham, https://www. odi.org/sites/odi.org.uk/files/odi-assets/publications-opinion-files/1110.pdf.

Egunyomi A. 1984. New records for the moss flora of Nigeria. Bryologist 87: 369-370.

EzUKANMA I. O. 2012. Survey of corticolous bryophytes in selected agroecological sites in Ibadan, Southwestern Nigeria. MSc Thesis. Department of Botany, University of Ibadan, Ibadan.

ECKel P. M. 2007. Hyophila. In: Flora OF NORTH AMERICA EDitorial Committee (eds), Flora of North America, North of Mexico. 27. Bryophyta 1: 584-585. Oxford University Press, New York, Oxford.

FlorschütZ-DE WAARD J. \& Florschütz P. A. 1979. Estudios sobre criptogamas colombianas III. Lista comentada de los musgos de Colombia. Bryologist 82: 215-259. 
ForzZA R. C. 2010. Lista de espécies Flora do Brasil. http:// floradobrasil.jbrj.gov.br/2010.

Frahm J.-P. 1982. New Campylopus records from South and Central America II. Bryologist 85: 322-323.

Frahm J.-P. 1985. Afrikanische Campylopus Arten (Dicranaceae, Musci). Bryophyt. Biblioth. 31: 1-216.

Frahm J.-P. 2003. Manual of Tropical Bryology. Trop. Bryol. 23: 1-196.

Gumnior M. \& Sommer V. 2012. Multi-Scale, multi-temporal vegetation mapping and assessment of ecosystem degradation at Gashaka Gunit National Park (Nigeria). Research Journal of Environmental and Earth Sciences 4(4): $397-412$.

Gradstein S. R. 1999. On the rediscovery of Spruceanthus theobromae (Lejeuneaceae, Hepaticae), an endangered species on cacao trees in western Ecuador. Bryobrothera 5: $81-86$.

Hedderson T. A. J., Gwynne-Evans D., Ah-Peng C. \& RIBEIRO D. 2015. A contribution to the bryoflora of Mozambique from the 'Google Forest', Mabu Mountain, Zambezia Province. J. Bryol. 37(1): 42-48.

Hodgetts N., O’Shea B. \& Pócs T. 2000. Sub-Saharan Africa: Biodiversity, centres of diversity, and endemism. In: T. Hallingback \& N. Hodgetts (eds), Mosses, Liverworts, and Hornworts, pp. 31-34. IUCN/SSC Bryophyte Specialist Group. IUCN, Gland, Switzerland and Cambridge, UK.

Hyvönen J. 1989. A synopsis of genus Pogonatum (Polytrichaceae, Musci). Acta Bot. Fenn. 138: 1-87.

Ihuma J. O., Chima U. D. \& Chapman H. M. 2011. Tree species diversity in a montane forest ecosystem and adjacent fragmented forests. ARPN Journal of Agriculture and Biological Science 6(2): 17-22. http://www.arpnjournals.com/ jabs/research_papers/rp_2011/jabs_0211_238.pdf.

JoHANSSON D. 1974. Ecology of vascular eopiphytes in West African rain forest. Acta Phytogeogr. Suec. 59: 1-129.

JoNes E. W. 1979. African hepatics. XXXI. Some new or littleknown Lejeuneaceae and extensions of range. J. Bryol. 10: $387-400$

Jones E. W. 1990. African Hepatics XLI. Some critical notes and new records. J. Bryol. 16: 41-44.

KeAY R. W. J. 1953. An outline of Nigerian vegetation. Second edition. Lagos: Government Printer.

KIs G. 1985. Mosses of South-East Tropical Africa. An annotated list with distributional data. Institute of Ecology and Botany of the Hungarian Academy of Sciences, Vácrátót, Hungary.

Manyanga Ph. \& Perold S. M. 2004. A checklist of Zimbabwean bryophytes. Southern African Botanical Diversity Network Report 21: 1-21.
Mubi A. M. \& Tukur A. L. 2012. Species density and diversity along geomorphic gradient in Gashaka-Gunit National Park (GGNP), Nigeria. Ethiopian Journal of Environmental Studies and Management 5(4, suppl. 1): 513-520.

Müller F. \& Pócs T. 2000. A contribution in the knowledge of epiphyllous bryophytes of Bioko Island (Equatorial Guinea), including additional remarks of non-epiphyllous species. J. Bryol. 29: 81-86.

Müller F., Pócs T. \& Shevock J. R. 2011. Addition to the liverwort and hornwort flora of São Tomé and Principe. J. Bryology 33: 19-22.

Newmaster S. G., Belland R. J., Arsenault A., Vitt D. H. \& STEPhens T. R. 2005. The ones we left behind: Comparing plot sampling and floristic habitat sampling for estimation bryophyte diversity. Diversity \& Distrib. 11: 57-72.

O'Shea B. J. 1995. Checklist of the mosses of sub-Saharan Africa. Trop. Bryol. 10: 91-198.

O'Shea B. J. 2006. Checklist of the mosses of sub-Sahara Africa (ver. 5,12/6). Tropical Bryology Reports 6: 1-252.

Petit E. 1978. Clefs pour la détermination des families et des genres des mousses pleurocarpes (Musci) d'Afrique. Bull. Jard. Bot. Natl. Belg. 48: 135-181.

Sollman P. 2013. A revision of the genus Hyophila Brid. (Musci, Pottiaceae) in Africa. Privately published, St Annaparochie.

Söderström L., Hagborg A., von Konrat M., Bartholomew-Began S., Bell D., Briscoe L., Brown E., Cargill D. C., Costa D. P., Crandall-Stotler B. J., Cooper E. D., Dauphin G., Engel J. J., Feldberg K., Glenny D., Gradstein S. R., He X., Heinrichs J., Hentschel J., Ilkiu-Borges A. L., Katagiri T., Konstantinova N. A, Larraín J., Long D. G., Nebel M., Pócs T., Felisa Puche F., Reiner-Drehwald E., Renner M. A. M., Sass-Gyarmati A., Schäfer-Verwimp A., Moragues J. G. S., Stotler R. E., Sukkharak P., Thiers B. M., Uribe J., VáŇa J., Villarreal J. C., Wigginton M., ZHANG L. \& ZHU R.-L. 2015. World checklist of hornworts and liverworts. PhytoKeys 59: 1-828. doi: 10.3897/ phytokeys.59.6261.

TAN B. C. \& Iwatsuki Z. 1991. A new annotated Philippines moss checklist. Harvard Pap. Bot. 3: 1-64.

Touw A. 1976. A taxonomic revision of Thuidium, Pelekium and Rauiella in Africa South of the Sahara. Lindbergia 3: 135-195.

Touw A. 2001. A review of the Thuidiaceae (Musci) and a realignment of taxa traditionally accommodated in Thuidium sensu amplo (Thuidium Schimp., Thuidiopsis (Broth.) M. Fleisch., and Pelekium Mitt.) including Aequatoriella gen. nov., and Indothuidium gen. nov. J. Hattori Bot. Lab. 90: $167-209$.

WALters M. 2017. An illustrated checklist of the flora of Ngel Nyaki forest reserve. [10 March 2017]. http://www. afromontane.canterbury.ac.nz/checklist.shtml. 
Wigginton M. J. 2004. E. W. Jones's Liwerwort and Hornwort Flora of West Africa. Scripta Bot. Belg. 30: XII + 1-433.

Wigginton M. J. 2009 Checklist and distribution of the liverworts and hornworts of sub-Saharan Africa, including the East African Islands (edition 3, 24 January 2009). Trop. Bryol. Res. Rep. 8: 1-116.
WiJk R. van der, Margadant W. D. \& Florschütz P. A. 1959-1969. Index Muscorum. Utrecht, Netherlands.

ZANDER R. H. 1994. Hyophilia. In: A. J. Sharp, H. Crum \& P. Eckel (eds), Moss Flora of Mexico. Mem. New York Bot. Gard. 69: 270-273. 